\title{
Treatment Dosing of Low-Molecular- Weight Heparins and the Dose Cap Dilemma: Considerations for Patients in Canada
}

\author{
Peter Thomson, Cynthia Brocklebank, and William Semchuk
}

\begin{abstract}
Background: In Canada, there is a dose cap for weight-based treatment with low-molecular-weight (LMW) heparins.

Objective: To review whether capping of LMW heparin doses is warranted for patients with obesity.

Methods: English-language publications concerning the use of LMW heparin in Canada were reviewed, and the literature regarding use of these drugs at treatment doses in patients with obesity was assessed.

Results: Five pharmacokinetic or pharmacodynamic studies meeting the inclusion criteria were identified. The evidence in those studies pointed toward no excess accumulation of LMW heparin in patients with obesity. In addition, 5 trials involving patients with acute coronary syndromes and 6 trials involving patients with venous thromboembolism and other indications were identified, but only 7 of these 11 trials included sufficient information for review. Subgroup analysis of patients with acute coronary syndrome whose LMW heparin dose was not capped showed no increased risk of bleeding for obese patients treated with enoxaparin. For patients with venous thromboembolism and other indications, the best evidence was for dalteparin, with anti-Xa levels used as a surrogate end point. In this setting, excess accumulation did not occur when there was no dose cap.

Discussion: There is little literature dedicated to the dosing of LMW heparin for obese patients. In particular, there are few data for those with body weight above $150 \mathrm{~kg}$. Despite the limitations of these studies, there appears to be little justification for capping the doses of these drugs. On the basis of the available literature, it is suggested that treatment doses of LMW heparin be based on body weight up to $150 \mathrm{~kg}$.
\end{abstract}

Key words: low-molecular-weight heparin, acute coronary syndrome, venous thromboembolism, dosing, obesity

Can J Hosp Pharm 2009;62(5):367-374

\section{RÉSUMÉ}

Contexte : Au Canada un plafond est fixé à la dose pour les traitements par l'héparine de faible poids moléculaire (HFPM) fondées sur le poids ont été établies.

Objectif : Évaluer si les doses limites d'HFPM sont justifiées chez les patients obèses.

Méthodes : Des publications de langue anglaise sur l'emploi d'HFPM au Canada ont été examinées et la littérature sur l'emploi d'HFPM à des doses thérapeutiques chez les patients obèses a été évaluée.

Résultats : Cinq études de pharmacocinétique ou de pharmacodynamie satisfaisant aux critères d'inclusion ont été recensées. Les données dans ces études portent à croire qu'il n'y a pas d'accumulation excessive de ces médicaments chez cette population de patients. En outre, cinq études menées sur le traitement de patients atteints de syndromes coronariens aigus et six autres sur le traitement de patients souffrant de thromboembolie veineuse et pour d'autres indications ont été identifiées, mais seulement sept de ces onze études comportaient suffisamment d'information pour être analysées. L'analyse de sous-groupes de patients atteints de syndrome coronarien aigu dont la dose d'HFPM ne respectait pas le plafond fixé n'a montré aucune augmentation du risque de saignement chez les patients obèses traités par l'énoxaparine. Chez les patients souffrant de thromboembolie veineuse et pour d'autres indications, les données les plus probantes étaient pour la daltéparine, avec les taux de facteur anti-Xa utilisés comme critère de substitution. Dans ce contexte, aucune accumulation excessive n'est survenue en l'absence d'un plafonnement de la dose.

Conclusions : Il existe peu de documentation portant sur la posologie de l'HFPM chez les patients obèses. On dispose de particulièrement peu de données pour les patients ayant un poids corporel supérieur à $150 \mathrm{~kg}$. Malgré les limites de ces études, le plafonnement des doses de l'HFPM semble peut justifié. La littérature disponible porte à croire que les doses thérapeutiques d'HFPM peuvent être fondées sur le poids corporel jusqu'à une taille de $150 \mathrm{~kg}$.

Mots clés : héparine de faible poids moléculaire, syndrome coronarien aigu, thromboembolie veineuse, posologie, obésité

[Traduction par l'éditeur] 


\section{INTRODUCTION}

$\mathrm{H}^{2}$ eparin (i.e., unfractionated heparin) combined with oral anticoagulant therapy has been the mainstay of both prophylaxis and treatment for patients who have venous thromboembolism or who are at risk of this condition. Lowmolecular-weight (LMW) heparins have increasingly replaced unfractionated heparin in the treatment of deep vein thrombosis with or without pulmonary embolism. The use of LMW heparins beyond the acute treatment period of venous thromboembolism occurs for selected patients in whom oral anticoagulation with warfarin may not be appropriate, primarily patients who experience recurrent thrombosis while taking warfarin and patients with active cancer.' Data also support the use of LMW heparin in acute coronary syndromes, and institutions commonly use these agents for such syndromes. LMW heparins are employed for other indications as well, such as bridging at the time of surgical procedures. For the vast majority of patients, weight-adjusted doses of LMW heparin can be administered subcutaneously once or twice daily without laboratory monitoring. ${ }^{1}$

The LMW heparins vary slightly from one another in the distribution of the molecular weight species they contain and in their pharmacologic properties. ${ }^{2}$ LMW heparins are hydrophilic agents that are primarily distributed to the intravascular space. In adults, their volume of distribution is typically about $0.05 \mathrm{~L} / \mathrm{kg}$ or about $4-6 \mathrm{~L}$..7 Although some drugs (e.g., aminoglycosides) are dosed on an estimated lean or adjusted body weight in obese patients, the activity of LMW heparins does not appear to be significantly increased when these drugs are dosed on the basis of total body weight. ${ }^{2,3.8}$ Peak pharmacologic effect (based on anti-Xa levels) ranges from 3 to $5 \mathrm{~h}{ }^{4.7}$

Dosage recommendations for the 4 LMW heparins marketed in Canada are based on weight up to a maximum between about 83 and $120 \mathrm{~kg}$. The dosage cap varies for each LMW heparin and for each indication (Table 1). ${ }^{4.7}$ In contrast, the regulatory agencies of many other countries have not placed a cap on the maximum dose.

According to the 2004 Canadian Community Health Survey for nutrition, $23 \%$ of Canadian adults are obese, as defined by body mass index (BMI) of $30 \mathrm{~kg} / \mathrm{m}^{2}$ or more. ${ }^{9}$ An unpublished survey of 480 patients referred for any indication to the Calgary Health Region Anticoagulation Management Service revealed that an average of $12.2 \%$ of patients weighed more than $100 \mathrm{~kg}$. Given current practices and Canadian demographics, determination of the optimal dose of LMW heparins for patients with obesity is clinically relevant. It is reasonable to assume that achieving adequate levels of anticoagulation in obese patients who are taking LMW heparins will affect outcomes such as morbidity, mortality, and risk of recurrent thrombosis.

In assessing the level of anticoagulation, the concentration of LMW heparins cannot be measured directly. The activity of anti-Xa activity is the primary indirect measure of their anticoagulant effect. In the Winnipeg Regional Health Authority, therapeutic peak anti-Xa levels at $4 \mathrm{~h}$ after dose administration for patients with venous thromboembolism (including pulmonary embolism) are defined as 1.0-2.0 U/mL with once-daily dosing of LMW heparin and $0.5-1.0 \mathrm{U} / \mathrm{mL}$ with twice-daily dosing. Two concerns related to use of the anti-Xa level to measure anticoagulant effect are that optimal target peak anti-Xa levels for LMW heparins are not well defined and there is a lack of data to support a link between the anti-Xa level and the clinical outcome. ${ }^{2,10}$ In addition to the use of anti-Xa levels as an indirect marker of efficacy, there is evidence that higher anti-Xa levels are associated with an increased risk of major bleeding. ${ }^{10}$

Many patients who are taking LMW heparins weigh more than the maximum dosing weight defined by the Canadian monographs. A literature review was therefore undertaken to determine the validity of the caps on treatment doses of LMW heparins marketed in Canada that have been set for obese patients.

\section{Table 1. Comparative Dosing Indications for Low-Molecular-Weight (LMW) Heparins from Canadian Product Monographs ${ }^{47}$}

\begin{tabular}{|c|c|c|c|}
\hline Indication and LMW Heparin & Recommended Dose & Maximum Dose & Weight for Dosage Cap(kg) \\
\hline \multicolumn{4}{|l|}{ Venous thromboembolism } \\
\hline Dalteparin & $\begin{array}{l}200 \mathrm{IU} / \mathrm{kg} \text { q24h or } \\
100 \mathrm{IJ} / \mathrm{kg} \mathrm{q} 12 \mathrm{~h}\end{array}$ & $18000 \mathrm{IU} / \mathrm{day}$ & 90 \\
\hline Enoxaparin & $\begin{array}{l}1.5 \mathrm{mg} / \mathrm{kg} \text { q2 } 4 \mathrm{~h} \text { or } \\
1 \mathrm{mg} / \mathrm{kg} \mathrm{q} 12 \mathrm{~h}\end{array}$ & $180 \mathrm{mg}$ single daily dose* & 120 \\
\hline Nadroparin & $171 \mathrm{IU} / \mathrm{kg}$ q24h & $17100 \mathrm{IU} / \mathrm{day}$ & 100 \\
\hline Tinzaparin & $175 \mathrm{IU} / \mathrm{kg}$ q24h & $18000 \mathrm{IU} / \mathrm{day}$ & 102.9 \\
\hline \multicolumn{4}{|l|}{ Acute coronary syndrome } \\
\hline Dalteparin & $120 \mathrm{IU} / \mathrm{kg} \mathrm{q12h}$ & $10000 \mathrm{IU} \mathrm{q12h}$ & 83.3 \\
\hline Enoxaparin & $1 \mathrm{mg} / \mathrm{kg}$ q12h & $100 \mathrm{mg} \mathrm{q} 12 \mathrm{~h}$ & 100 \\
\hline Nadroparin & About 86 IU/kg q12h & $9500 \mathrm{IU} \mathrm{q12h}$ & 110.4 \\
\hline
\end{tabular}

*No maximum dose specified for single daily dose. 


\section{METHODS}

A review was conducted of English-language publications with information related to dosing and outcomes for obese patients receiving any of the $4 \mathrm{LMW}$ heparins marketed in Canada. MEDLINE, PubMed, CINAHL (the Cumulative Index to Nursing and Allied Health Literature), and International Pharmaceutical Abstracts (IPA) were searched with the following search terms: "low molecular weight heparin", "acute coronary syndrome", "orthopedics", "venous thromboembolism", and "obesity". All terms were searched separately and in combination with "warfarin". Authors of identified articles were not contacted to determine availability of other unpublished data. The review focused on clinical and pharmacokinetic studies of each of the 4 agents, administered at therapeutic treatment doses for venous thromboembolism, acute coronary syndromes, or other indications in obese patients. Studies involving prophylactic doses of LMW heparins were excluded.

\section{RESULTS}

\section{Pharmacokinetic Studies with LMW Heparins in Obesity}

Most of the reports of the pharmacokinetics and pharmacodynamics of LMW heparins in obesity are from open-label studies involving a very limited number of otherwise healthy volunteers (Table 2), ${ }^{3,11-13}$ Anti-Xa levels were used extensively as a measure of efficacy, and the results did not differ significantly between obese and nonobese patients receiving doses according to total body weight. These findings suggest that excess drug accumulation did not occur in these obese volunteers.

One pharmacokinetic study of weight-adjusted dosing of nadroparin was identified, but it was excluded from this review because it addressed prophylaxis only. ${ }^{14}$

A Canadian study in a Quebec hospital followed patients given enoxaparin for a variety of indications (e.g., 33.5\% of patients with atrial fibrillation, $22.7 \%$ with myocardial

Table 2. Low-Molecular-Weight (LMW) Heparins in Obesity: Pharmacokinetic and Pharmacodynamic Studies

\begin{tabular}{|c|c|c|c|c|c|}
\hline Study & LMW Heparin & Population & Design & Intervention & Results \\
\hline $\begin{array}{l}\text { Yee and } \\
\text { Duffull }^{11}\end{array}$ & Dalteparin & $\begin{array}{l}\text { Normal weight } \\
(n=10) \\
\text { Obese,BMl } \geq \\
30 \mathrm{~kg} / \mathrm{m}^{2}(n=10) \\
\text { Patients matched } \\
\text { on treatment }\end{array}$ & Open label & $\begin{array}{l}200 \text { U/kg daily } \\
\text { (VTE) or } \\
120 \text { U/kg } \\
\text { q12h (ACS) }\end{array}$ & $\begin{array}{l}\text { Volume of distribution and } \\
\text { clearance not significantly } \\
\text { different; mean clearance } \\
1.30 \mathrm{~L} / \mathrm{h} \text { for obese } \\
\text { participants, } 1.11 \mathrm{~L} / \mathrm{h} \text { for } \\
\text { participants with normal } \\
\text { weight }\end{array}$ \\
\hline
\end{tabular}

\begin{tabular}{|c|c|c|c|c|c|c|}
\hline $\begin{array}{l}\text { Sanderink } \\
\text { et al. }{ }^{3}\end{array}$ & Enoxaparin & $\begin{array}{l}\text { Normal weight } \\
(n=24) \\
\text { Obese, BMl } \\
30-40 \mathrm{~kg} / \mathrm{m}^{2}(n=24) \\
\text { Otherwise healthy } \\
\text { volunteers }\end{array}$ & $\begin{array}{l}\text { Open label } \\
\text { Cross-over }\end{array}$ & $\begin{array}{l}1.5 \mathrm{mg} / \mathrm{kg} \text { daily } \\
\mathrm{SC} \text { for } 4 \text { days } \\
\text { and } 1.5 \mathrm{mg} / \mathrm{kg} \\
\text { single-dose } \\
\text { infusion }\end{array}$ & $\begin{array}{l}\text { Peak anti-Xa activity similar } \\
\text { between groups } \\
T_{\max } \text { delayed by } 1 \mathrm{~h} \text { in } \\
\text { obese subjects } \\
\text { Day } 4 \text { AUC for anti-Xa } \\
\text { activity } 19 \% \text { higher among } \\
\text { obese participants than } \\
\text { among healthy participants }\end{array}$ & $\begin{array}{l}\text { Authors concluded that } \\
\text { dosing based on total body } \\
\text { weight is appropriate up to } \\
\text { BMl of } 40 \mathrm{~kg} / \mathrm{m}^{2}\end{array}$ \\
\hline $\begin{array}{l}\text { Bazinet } \\
\text { et al. }{ }^{12}\end{array}$ & Enoxaparin & $\begin{array}{l}\text { Nonobese, BMl } \\
18-30 \mathrm{~kg} / \mathrm{m}^{2} \\
(n=133) \\
\text { Obese, BMl } \\
>30 \mathrm{~kg} / \mathrm{m}^{2}(n=81) \\
\text { Patients receiving } \\
\text { treatment for various } \\
\text { indications }\end{array}$ & Open label & $\begin{array}{l}1.5 \mathrm{mg} / \mathrm{kg} \text { daily } \\
\text { or } 1 \mathrm{mg} / \mathrm{kg} \text { bid }\end{array}$ & $\begin{array}{l}\text { With } 1.5 \mathrm{mg} / \mathrm{kg} \text { daily, mean } \\
\text { anti-Xa level } 1.13 \text { for } \\
\text { nonobese participants, } \\
1.15 \text { for obese participants } \\
\text { With } 1 \mathrm{mg} / \mathrm{kg} \mathrm{q} 12 \mathrm{~h} \text {, mean } \\
\text { anti-Xa levels } 1.12 \text { for } \\
\text { nonobese participants, } \\
1.17 \text { for obese participants }\end{array}$ & $\begin{array}{l}\text { Anti-Xa levels obtained } 4 \mathrm{~h} \\
\text { after dosing } \\
\text { Anti-Xa activity did not } \\
\text { vary with BMl } \\
\text { On basis of anti-Xa activity } \\
\text { levels, authors concluded } \\
\text { that dose adjustment not } \\
\text { required for obese patients } \\
\text { Weight range of obese } \\
\text { patients: } 66-136 \mathrm{~kg}\end{array}$ \\
\hline Hainer et al. ${ }^{13}$ & Tinzaparin & $\begin{array}{l}\text { Normal weight } \\
(n=23) \text {, historical } \\
\text { controls } \\
\text { Obese, }>100 \mathrm{~kg} \text { or } \\
\mathrm{BMl}>30 \mathrm{~kg} / \mathrm{m}^{2} \\
(n=36) \\
\text { Otherwise healthy } \\
\text { volunteers }\end{array}$ & $\begin{array}{l}\text { Open label } \\
\text { Cross-over }\end{array}$ & $\begin{array}{l}\text { Single doses of } \\
75 \mathrm{U} / \mathrm{kg} \text { and } \\
175 \mathrm{U} / \mathrm{kg}\end{array}$ & $\begin{array}{l}\text { No effect of body weight } \\
\text { or BMl on anti-Xa or lla } \\
\text { levels in normal or obese } \\
\text { participants with either } \\
\text { dose } \\
\text { Mean anti-Xa maximal } \\
\text { activity with } 175 \mathrm{U} / \mathrm{kg} \\
0.87 \text { v. } 0.81 \mathrm{IU} / \mathrm{mL}\end{array}$ & $\begin{array}{l}45.9 \% \text { of obese patients } \\
\text { had BMl > } 45 \mathrm{~kg} / \mathrm{m}^{2} \\
\text { Weight range of obese } \\
\text { patients } 101-165 \mathrm{~kg} \\
\text { Authors concluded that } \\
\text { weight-based dosing is } \\
\text { appropriate regardless of } \\
\text { total body weight }\end{array}$ \\
\hline
\end{tabular}

$\overline{\mathrm{ACS}}=$ acute coronary syndrome, $\mathrm{AUC}=$ area under the curve, $\mathrm{BMI}=$ body mass index,

$T_{\max }=$ time to maximum concentration, $\mathrm{VTE}=$ venous thromboembolism. 
infarction, $20.6 \%$ with unstable angina). ${ }^{12}$ There was no maximum dose (i.e., no dose cap) for enoxaparin. Anti-Xa levels after 2-3 days of enoxaparin therapy were available for 214 patients, 81 of whom were categorized as being obese (range 66-136 kg). Mean anti-Xa levels $4 \mathrm{~h}$ after dose administration for patients with healthy weight $\left(18-30 \mathrm{~kg} / \mathrm{m}^{2}\right)$ and those who were obese $\left(>30 \mathrm{~kg} / \mathrm{m}^{2}\right)$ were virtually identical in both the once-daily and twice-daily administration groups. Although bleeding rates were tracked, there was no comment on bleeding rates in relation to body weight. Anti-Xa levels were similar for those who experienced bleeding and those who did not.

From these pharmacokinetic-pharmacodynamic studies, there does not appear to be any evidence supporting the use of a dose cap for LMW heparins used at treatment doses in obese patients (defined on the basis of either total body weight or BMI). There is a lack of evidence regarding nadroparin at treatment doses in obesity.

\section{Acute Coronary Syndromes}

Two trials of LMW heparins in acute coronary syndromes included obese patients and published patients' body weights (Table 3). ${ }^{15,16}$ Three studies of LMW heparins in acute coronary syndromes were excluded from this review, as they did not provide any subgroup analyses for bleeding rates, event rates, or anti-factor Xa levels according to patient weight. ${ }^{17-19}$ Two large trials of enoxaparin in acute coronary syndromes published more recently included insufficient details about patient weight to allow analysis for this review. ${ }^{20,21}$

In 1996, the first large-scale trial of dalteparin in acute coronary syndromes was published. ${ }^{15}$ Subgroup analysis of the primary end point compared patients with BMI less than $26 \mathrm{~kg} / \mathrm{m}^{2}$ with patients whose BMI was $26 \mathrm{~kg} / \mathrm{m}^{2}$ or above. The risk ratio for death or myocardial infarction during the first 6 days of dalteparin therapy (relative to placebo) was statistically significant only for patients with BMI less than $26 \mathrm{~kg} / \mathrm{m}^{2}$. The risk ratio for patients with BMI of $26 \mathrm{~kg} / \mathrm{m}^{2}$ or above was not statistically significant, which the study authors attributed to the small sample size $(n=356$ patients with BMI of $26 \mathrm{~kg} / \mathrm{m}^{2}$ or above in the active treatment group). The potential affect of the dose maximum of 10000 units was not examined for this higher BMI subgroup, even though patients with BMI up to $44 \mathrm{~kg} / \mathrm{m}^{2}$ were included in the study.

The largest pool of patients with both obesity and acute coronary syndrome treated with LMW heparin (enoxaparin) comes from a review ${ }^{16}$ of the treatment effects on obese patients and those with renal dysfunction enrolled in the

Table 3. Low-Molecular-Weight (LMW) Heparins in Obesity: Acute Coronary Syndromes*

\begin{tabular}{|c|c|c|c|c|c|c|}
\hline Study & $\begin{array}{l}\text { LMW } \\
\text { Heparin }\end{array}$ & Design & Intervention & $\begin{array}{l}\text { Primary } \\
\text { Outcome }\end{array}$ & Results & Comments \\
\hline $\begin{array}{l}\text { FRISC study } \\
\text { group }^{15}\end{array}$ & Dalteparin & $\begin{array}{l}\text { Randomized, } \\
\text { double-blind, } \\
\text { placebo-controlled } \\
\text { trial }\end{array}$ & $\begin{array}{l}\text { Placebo }(n=760) \\
\text { Dalteparin } 120 \\
\text { IU/kg bid for } 6 \\
\text { days }(n=746) \text {, } \\
\text { then } 7500 \mathrm{IU} \\
\text { daily for next } \\
35-45 \text { days }\end{array}$ & $\begin{array}{l}\text { Death or } \\
\text { myocardial } \\
\text { infarction in } \\
\text { first } 6 \text { days }\end{array}$ & $\begin{array}{l}\text { Primary outcome (day 6) by } \\
\text { weight, dalteparin v. placebo: } \\
\text { For BMl }<26 \mathrm{~kg} / \mathrm{m}^{2} \text {, } \\
\text { RR } 0.14,95 \% \mathrm{Cl} 0.05-0.40 \\
\text { For BMl } \geq 26 \mathrm{~kg} / \mathrm{m}^{2} \\
\text { RR } 0.63,95 \% \mathrm{Cl} 0.27-1.46 \\
\text { For weight }<76 \mathrm{~kg}, \mathrm{RR} 0.29 \text {, } \\
95 \% \mathrm{Cl} 0.11-0.77 \\
\text { For weight } \geq 76 \mathrm{~kg}, \\
\text { RR } 0.41,95 \% \mathrm{Cl} 0.18-0.92 \\
\text { Similar rates of major } \\
\text { bleeding at day } 6 \\
(0.8 \% \text { v. } 0.5 \%)\end{array}$ & $\begin{array}{l}\text { Median body weight, } \\
\text { dalteparin group, } 75 \mathrm{~kg} \\
\text { (range } 47-125 \mathrm{~kg} \text { ) } \\
\text { Median BMI } 26 \mathrm{~kg} / \mathrm{m}^{2} \\
\left.\text { (range } 18-44 \mathrm{~kg} / \mathrm{m}^{2}\right) \\
120 \mathrm{IU} / \mathrm{kg} \text { dalteparin dose } \\
\text { capped at } 10000 \\
\text { U/dose }(83.3 \mathrm{~kg} \text { ) }\end{array}$ \\
\hline Spinler et al. & Enoxaparin & $\begin{array}{l}\text { Subgroup analysis } \\
\text { of ESSENCE and } \\
\text { TIMI 11B trials }\end{array}$ & $\begin{array}{l}\text { IV UFH }(n=3481 ; \\
\text { obese } n=918) \\
\text { Enoxaparin } \\
1 \mathrm{mg} / \mathrm{kg} \mathrm{q} 12 \mathrm{~h} \\
(n=3516 ; \\
\text { obese } n=921) \\
\text { Obese, BMl } \geq 30\end{array}$ & $\begin{array}{l}\text { Composite end } \\
\text { point of death, } \\
\text { myocardial } \\
\text { infarction, urgent } \\
\text { revascularization } \\
\text { at } 43 \text { days }\end{array}$ & $\begin{array}{l}\text { Primary outcome, } \\
\text { enoxaparin v. UFH: } \\
\text { For obese patients: } 14.3 \% \\
\text { v. } 18 \%, p=0.05 \\
\text { For nonobese patients: } \\
16.1 \% \text { v. } 19.2 \% \text {, } \\
p<0.01 \\
\text { Difference in primary end } \\
\text { point, all treatments, } \\
\text { obese v. nonobese patients: } \\
17.6 \% \text { v. } 16.2 \%, p=0.39 \\
\text { For enoxaparin only, obese } \\
\text { v. nonobese patients: major } \\
\text { hemorrhage } 0.4 \% \text { v. } 1.6 \%, \\
\text { any bleeding } 11.7 \% \text { v. } 9.5 \%\end{array}$ & $\begin{array}{l}\text { ESSENCE weight range } \\
\text { for patients receiving } \\
\text { enoxaparin (mean } \pm \text { SD): } \\
94.3 \pm 14.3 \mathrm{~kg} \text { (range } \\
60-158.6 \mathrm{~kg} \text { ) } \\
\text { TIMl } 11 \mathrm{~B} \text { weight range for } \\
\text { patients receiving } \\
\text { enoxaparin (mean } \pm \text { SD): } \\
73 \pm 11.4 \mathrm{~kg} \\
\text { (range } 34-111 \mathrm{~kg}) \\
\end{array}$ \\
\hline
\end{tabular}

$\overline{\mathrm{ACl}}=$ confidence interval, $\mathrm{BMI}=$ body mass index, $\mathrm{Cl}=$ confidence interval, ESSENCE = Efficacy and Safety of Subcutaneous Enoxaparin in Non-Q-Wave Coronary Events, RR = risk ratio, SD = standard deviation, TIMI = Thrombolysis in Myocardial Infarction study, UFH = unfractionated heparin.

*Trials with weight-based subgroup analysis. 
Efficacy and Safety of Subcutaneous Enoxaparin in Non-QWave Coronary Events (ESSENCE) $)^{22}$ and Thrombolysis in Myocardial Infarction (TIMI) $11 \mathrm{~B}^{23}$ studies. In these 2 landmark trials of acute coronary syndrome, the primary composite end point of death, myocardial infarction, and urgent revascularization was lower with LMW heparins than with adjusted-dose IV unfractionated heparin. In both studies, there was no cap on the enoxaparin dose. The highest recorded weight in the trials was $144 \mathrm{~kg}$. About $26 \%$ of the patients in the ESSENCE and TIMI 11B trials were obese. The difference between the study groups reached statistical significance for nonobese patients, but the trend appeared consistent for the obese patients $(p=0.05)$. The outcome of all bleeding occurred more frequently among enoxaparin-treated patients, in both the obese and the nonobese groups. The difference for major bleeding was not as consistent as it was for all bleeding. Although not statistically significant, there was a trend toward more major bleeding among obese patients receiving unfractionated heparin than among those receiving enoxaparin $(1.2 \%$ versus $0.4 \%, p=0.08)$. In nonobese patients, the opposite occurred, with a trend toward greater rates of major bleeding among the enoxaparin-treated patients (1.0 versus $1.6 \%, p=0.08)$.

In summary, of 5 trials of acute coronary syndromes that enrolled obese patients, only 2 analyzed the obese participants as a subgroup. ${ }^{15,16}$ Only the trials with enoxaparin provided substantial details on outcomes for this patient group. ${ }^{16}$ The dose of enoxaparin was not capped in either study, and there was no evidence of a greater risk of bleeding with the larger doses used for obese subjects. ${ }^{16}$

\section{Dosing of LMW Heparin in Obesity for Venous Thromboembolism and Other Indications}

Six trials were identified that documented dosing of LMW heparin in obese patients with venous thromboembolism and other indications. ${ }^{24-29}$ One of these trials compared once-daily and twice-daily nadroparin for treatment of this condition..$^{29} \mathrm{In}$ that study, patients weighing more than $90 \mathrm{~kg}$ each received 18450 IU of nadroparin (maximum body weight $120 \mathrm{~kg}$ ). Because the study included no comments on the impact of obesity on patients' outcomes, this study was excluded from the current review. The remaining 5 trials $^{24-28}$ are summarized in Table 4.

The Enoxaparin Clinical Trial Group ${ }^{24}$ compared enoxaparin doses of $1.5 \mathrm{mg} / \mathrm{kg}$ once daily or $1 \mathrm{mg} / \mathrm{kg}$ twice daily with adjusted-dose IV unfractionated heparin. Of the 900 patients enrolled in the study, 405 were obese (defined on the basis of BMI). Among the patients who received enoxaparin, weight ranged from 44 to $155 \mathrm{~kg}$. Subgroup analysis indicated that cancer and symptomatic pulmonary embolism were significant risk factors for recurrent venous thromboembolism in all 3 treatment groups. Obesity was also a significant risk factor for recurrence for the 2 enoxaparin-treated groups. A nonsignificant trend toward recurrence with once-daily enoxaparin was observed at 3 months among obese patients: $7.3 \%$ for once-daily and $3.4 \%$ for twice-daily dosing $(p=0.18$ by 2 -sided Fisher's exact test). On the basis of these results, some have advocated twice-daily dosing of enoxaparin for obese patients. ${ }^{30}$

In 2 small trials, ${ }^{25,26}$ dalteparin was administered without a dose cap for obese patients; the surrogate end point examined was anti-Xa levels. In the first of these studies, ${ }^{25}$ a review of obese patients receiving dalteparin for bridging therapy, samples were drawn from 21 patients for measurement of antiXa levels $4 \mathrm{~h}$ after the second or third dose. In 2 of the 21 patients, the anti-Xa level was above the target range; both of these patients were receiving $100 \mathrm{U} / \mathrm{kg}$ twice daily. In 4 of the patients, anti-Xa was below the target range; all of these patients were receiving $200 \mathrm{U} / \mathrm{kg}$ once daily. The duration of therapy and patient outcomes were not reported.

A group from Nova Scotia examined patients receiving a minimum of 5 days of dalteparin therapy for venous thromboembolism. ${ }^{26}$ The mean duration of therapy was about 6.5 days. The authors grouped patients into 3 categories on the basis of degree of obesity. LMW heparin doses were not capped, and dosages ranged from 11200 to $38000 \mathrm{U} /$ day. There was no difference in anti-Xa levels among the 3 groups at any of the time points. Overall, peak anti-Xa levels tended to be low for once-daily dosing.

The outcomes for obese patients receiving dalteparin for acute venous thromboembolism were reported in a retrospective study from Ontario. ${ }^{27}$ About $5 \%$ of the patients weighed more than $150 \mathrm{~kg}$. By the end of the 3-month follow-up period, 2 patients had experienced an episode of major bleeding, both of which occurred long after the course of dalteparin had been completed. One of the 3 recurrent thromboembolic events occurred within the first month of therapy. The authors concluded that dalteparin could be administered for acute venous thromboembolism, at full treatment doses and without a dose cap, without increasing the risk of major hemorrhage.

A Spanish registry study evaluated clinical outcomes over 15 days among patients with a diagnosis of venous thromboembolism according to 3 weight categories. ${ }^{28}$ Two hundred and ninety-four patients in the registry weighed more than $100 \mathrm{~kg}$ (mean weight $112 \mathrm{~kg}$, range 101-160 kg). The mean daily dose ( \pm standard deviation) of the unspecified LMW heparins was $148 \pm 36 \mathrm{IU} / \mathrm{kg}$ for patients weighing more than $100 \mathrm{~kg}$, with $74 \%$ of these patients receiving less than 175 $\mathrm{IU} / \mathrm{kg}$. Some of the study sites used a cap on the LMW heparin dose. No statistically significant difference in recurrent venous 
Table 4. Low-Molecular-Weight (LMW) Heparins in Obesity: Venous Thromboembolism and Other Indications*

\begin{tabular}{|c|c|c|c|c|}
\hline Study & Intervention & Design & Results & Comments \\
\hline Merli et al. ${ }^{24}$ & $\begin{array}{l}\text { Enoxaprin } 1.5 \mathrm{mg} / \mathrm{kg} \\
\text { once daily }(n=298, \\
\text { obese } n=137) \\
\text { Enoxaparin } 1 \mathrm{mg} / \mathrm{kg} \text { bid } \\
(n=312 \text {, obese } \\
n=146) \\
\text { IV UFH }(n=290 \text {, obese } \\
n=122) \\
\text { Treatment for } \geq 5 \mathrm{~d} \\
\text { Warfarin started within } \\
72 \mathrm{~h} \text {, continued } \\
\text { for } \geq 3 \text { mo }\end{array}$ & $\begin{array}{l}\text { Randomized, } \\
\text { controlled, partially } \\
\text { blinded } \\
\text { All patients had } \\
\text { symptomatic lower- } \\
\text { extremity DVT }\end{array}$ & $\begin{array}{l}\text { Recurrent VTE events (NS) for } \\
\text { evaluable patients: } \\
\text { Enoxaparin } 1.5 \mathrm{mg} / \mathrm{kg} \text { per day } \\
\text { (4.5\%), } 1 \mathrm{mg} / \mathrm{kg} \text { bid ( } 3.1 \%) \text {, } \\
\text { IV UFH (4.3\%) } \\
\text { Recurrent VTE in obese patients } \\
\text { (7.3\% v. } 3.4 \% \text { v. } 2.5 \%) \\
\text { Any hemorrhage during study (NS): } \\
\text { Enoxaparin } 1.5 \mathrm{mg} / \mathrm{kg} \text { per day } \\
\text { (15.4\% v. } 17.3 \% \text { v. } 13.4 \%) \\
\text { Major bleeding } \\
(1.7 \% \text { v. } 2.2 \% \text { v. } 2.1 \%)\end{array}$ & $\begin{array}{l}\text { Obesity defined as BMI }>26.9 \mathrm{~kg} / \mathrm{m}^{2} \text { in } \\
\text { women, }>27.2 \mathrm{~kg} / \mathrm{m}^{2} \text { in men; } 45 \% \text { of } \\
\text { patients were obese } \\
\text { Obesity was predefined subgroup in data } \\
\text { analysis } \\
\text { Overall rate of recurrent VTE in evaluable } \\
\text { patients: } 4.4 \% \text { for obese patients v. } 3.9 \% \text { for } \\
\text { entirestudy population. Rates tended to be } \\
\text { higher in both obese enoxaparin groups v. } \\
\text { nonobese patients and lower for obese patients } \\
\text { receiving IV UFH (data not presented in study) } \\
136 \text { patients discontinued therapy early } \\
\text { Data presented for both all treated and } \\
\text { evaluable patients }\end{array}$ \\
\hline $\begin{array}{l}\text { Smith and } \\
\text { Canton }{ }^{25}\end{array}$ & $\begin{array}{l}\text { Dalteparin } 200 \mathrm{U} / \mathrm{kg} \\
\text { once daily or } 100 \mathrm{U} / \mathrm{kg} \\
\text { bid for bridging }(n=21)\end{array}$ & $\begin{array}{l}\text { Retrospective, } \\
\text { open label } \\
\text { All patients obese } \\
(>90 \mathrm{~kg})\end{array}$ & $\begin{array}{l}\text { Peak anti-Xa levels (3.5-5 h after } \\
\text { administration of drug) within } \\
\text { target for } 71.4 \% \text {, above target } \\
\text { for } 9.5 \% \text {, below target for } 19.0 \%\end{array}$ & $\begin{array}{l}\text { No dose cap } \\
\text { Weight range 94-176 kg } \\
\text { Target peak anti-Xa: } 0.5-1.0 \mathrm{U} / \mathrm{mL} \text { for bid drug } \\
\text { administration; } 1.0-2.0 \mathrm{U} / \mathrm{mL} \text { for once-daily } \\
\text { drug administration } \\
\text { Duration of therapy and patient outcomes } \\
\text { not reported }\end{array}$ \\
\hline Wilson et al. ${ }^{26}$ & $\begin{array}{l}\text { Dalteparin } 200 \mathrm{U} / \mathrm{kg} \\
\text { once daily for } \geq 5 \mathrm{~d} \\
\text { All obese patients, } \\
\text { assigned to } 3 \text { groups } \\
\text { based on IBW } \\
<20 \% \text { IBW }(n=13) \\
20 \%-40 \% \text { IBW }(n=14) \\
>40 \% \text { IBW }(n=10)\end{array}$ & $\begin{array}{l}\text { Anti-Xa levels } \\
\text { obtained at } 3 \text { time } \\
\text { points: peak day } 3 \\
\text { trough day 3, day } 5 \\
\end{array}$ & $\begin{array}{l}\text { Anti-Xa levels similar between } \\
\text { groups at all time points; mean } \\
\text { peak day } 3 \text { anti-Xa: } 1.01 \mathrm{U} / \mathrm{mL} \text { for } \\
\text { those }<20 \% \mathrm{IBW}, 0.97 \mathrm{U} / \mathrm{mL} \text { for } \\
\text { those } 20 \%-40 \% \mathrm{IBW}, \\
1.12 \mathrm{U} / \mathrm{mL} \text { for those }>40 \% \mathrm{IBW} \text {, } \\
p>0.2 \\
\text { Average of } 3 \text { peak anti-Xa levels } \\
\text { for all groups ranged from } \\
0.85 \text { to } 1.28 \mathrm{U} / \mathrm{mL}\end{array}$ & $\begin{array}{l}\text { No dose cap } \\
\text { Weight range 56-190 kg }\end{array}$ \\
\hline$\overline{\text { Al-Yaseen et al. } .^{27}}$ & $\begin{array}{l}\text { Dalteparin } 200 \mathrm{IU} / \mathrm{kg} \\
\text { once daily or } 100 \mathrm{IU} / \mathrm{kg} \\
\text { bid } \times 5-7 \mathrm{~d}+\text { warfarin } \\
\geq 3 \mathrm{mo}(n=193) \\
\text { All patients obese } \\
(>90 \mathrm{~kg})\end{array}$ & $\begin{array}{l}\text { Retrospective } \\
\text { emergency and } \\
\text { outpatient referrals } \\
\text { to clinic for acute } \\
\text { VTE treatment }\end{array}$ & $\begin{array}{l}\text { Recurrent VTE } 1.6 \% \text { at } 3 \text { mo } \\
\text { Major bleeding } 1 \% \text { (at } 4 \text { and } 8 \text { wk } \\
\text { after diagnosis) }\end{array}$ & $\begin{array}{l}\text { Mean weight } 114.2 \mathrm{~kg} \text { (range 91-182 kg) } \\
42 \text { patients received }<190 \mathrm{U} / \mathrm{kg} \text { to allow } \\
\text { use of prefilled syringes }\end{array}$ \\
\hline Barba et al..$^{28}$ & $\begin{array}{l}\text { Any LMW or UFH in } \\
\text { patients with acute } \\
\text { symptomatic VTE, } \\
\text { divided into } 3 \text { groups: } \\
<50 \mathrm{~kg}(n=169 \text {, } \\
\text { LMW } n=161) \\
50-100 \mathrm{~kg}(n=8382 \text {, } \\
\text { LMW } n=7559) \\
>100 \mathrm{~kg}(n=294, \\
\text { LMW } n=242)\end{array}$ & $\begin{array}{l}\text { Retrospective analysis } \\
\text { of registry data from } \\
94 \text { hospitals in } \\
\text { Spain }\end{array}$ & $\begin{array}{l}\text { Recurrent VTE rates similar } \\
<50 \mathrm{~kg} \text { v. } 50-100 \mathrm{~kg} \text { v. }>100 \mathrm{~kg} \\
(1.2 \% \text { v. } 1.0 \% \text { v. } 0.7 \%) \\
\text { Major bleeding rates similar at } \\
15 \text { days (3.0\% v. } 1.3 \% \text { v. } 1.0 \%)\end{array}$ & $\begin{array}{l}\text { Weight range for obese patients } 101-160 \mathrm{~kg} \\
\text { Dose of LMW capped at some sites } \\
\text { (not defined in study) } \\
\text { Mean LMW dose for patients > } 100 \mathrm{~kg} \\
\text { was } 148 \mathrm{U} / \mathrm{kg} \\
\text { Initial LMW }<175 \mathrm{U} / \mathrm{kg} \text { per day: } 22 \% \text { of those } \\
<50 \mathrm{~kg}, 33 \% \text { of those } 50-100 \mathrm{~kg}, 74 \% \\
\text { of those }>100 \mathrm{~kg} \\
\text { Mean LMW/d } 208 \mathrm{U} / \mathrm{kg} \text { for those }<50 \mathrm{~kg} \text {, } \\
181 \mathrm{U} / \mathrm{kg} \text { for those } 50-100 \mathrm{~kg}, 148 \mathrm{U} / \mathrm{kg} \text { for } \\
\text { those }>100 \mathrm{~kg} \\
\text { Difficult to draw conclusions about clinical } \\
\text { outcomes from 15-day follow-up }\end{array}$ \\
\hline
\end{tabular}

$\overline{\mathrm{BMI}}=$ body mass index, DVT = deep vein thrombosis, IBW = ideal body weight, NS = not significant, UFH = unfractionated heparin,

$\mathrm{VTE}=$ venous thromboembolism

*Trials with weight-based subgroup analysis.

thromboembolism or major bleeding was observed between the weight groups.

Of the 6 trials of LMW heparins for venous thromboembolism and other indications, only 5 trials (involving enoxaparin and dalteparin) provided evaluable data. ${ }^{24-28}$ The trial of enoxaparin included a subgroup analysis of a larger group and evaluated 2 different dosage regimens. ${ }^{24}$ In that study, no dose cap was used and there was no increase in the rate of bleeding. The best data regarding LMW heparins in obesity for these indications are for dalteparin. Both the retrospective evaluation from Ontario ${ }^{27}$ and the 2 studies using anti-Xa levels as a surrogate end point ${ }^{25,26}$ suggest that efficacy and safety are not compromised by dosing dalteparin according to actual body weight.

Few obese patients have been enrolled in the major trials of LMW heparins for treatment of venous thromboembolism. 
A 2001 review of LMW heparins in special populations ${ }^{31}$ concluded that the dosage of LMW and body surface area or BMI may correlate with anti-Xa activity, bleeding, and thromboembolic outcomes. The authors of the review recommended that the dose of LMW heparins be calculated according to total body weight in kilograms. In that review, the highest reported total body weights for patients receiving treatment for acute venous thromboembolism were $159 \mathrm{~kg}$ with enoxaparin and $190 \mathrm{~kg}$ with dalteparin. ${ }^{31}$

\section{DISCUSSION}

In evaluating the issue of dosing caps for LMW heparins, there is a paucity of data from which to draw conclusions. Assessment of this issue is dependent on data primarily from pharmacokinetic studies in healthy volunteers, post hoc or subgroup analyses from trials of acute coronary syndromes and venous thromboembolism, and small clinical trials using anti-Xa levels as a surrogate marker of efficacy. Given the prevalence of obesity, it would be helpful if more literature were available on dosing of LMW heparins in obese patients.

The best outcome data reviewed here were for the use of LMW heparins in acute coronary syndromes. The review by Spinler and others ${ }^{16}$ of enoxaparin use in the ESSENCE and TIMI 11B trials is the largest of these. For more than 900 obese patients, there was no evidence that dosing of enoxaparin according to total body weight, without a dose cap, increased the rate of bleeding relative to IV unfractionated heparin. The authors of the review suggested that obese patients with acute coronary syndromes who were treated with enoxaparin had better outcomes than those treated with unfractionated heparin, but to our knowledge, this result has not been confirmed for treatment doses capped at $120 \mathrm{~kg}$.

Both of the small-scale trials that examined peak anti-Xa levels in obese patients treated with dalteparin drew similar conclusions. ${ }^{25,26}$ In one study, the patients were receiving bridging therapy, and in the other the treatment was for venous thromboembolism. Although these 2 trials had design limitations (e.g., small numbers, open-label, no event rates), both supported the removal of a dose cap to achieve target peak anti-Xa levels. ${ }^{25,26}$ There was no evidence of excessive accumulation without a dose cap.

In a Pharmacia newsletter published in 2001,32 the manufacturer stated that "experience with a maximum daily-dose of $18000 \mathrm{aXaU}$ [units] in pivotal studies has shown similar effectiveness and tolerability in patients $>90 \mathrm{~kg}$ as compare [sic] with patients $<90 \mathrm{~kg}$, therefore, from an efficacy standpoint giving more than $18000 \mathrm{IU}$ per day would not be expected to improve outcomes". However, this comment was not referenced in the newsletter.

Despite the limitations of the published data, what literature was found in this review suggests that there is little justification for capping doses of LMW heparin. Most of the evidence reviewed here supports dosing based on total body weight. Others have drawn similar conclusions, ${ }^{2,30,33}$ whereas at least one group was less confident about drawing any conclusions, given the insufficiency of the data. ${ }^{10}$

Whether doses of LMW heparin should be given as a single daily dose or divided into a twice-daily dose for obese patients is debatable. As well, obese patients with comorbidities that alter drug clearance have not been well studied. The most important group in this situation would be obese patients with renal insufficiency.

Very little information is available for patients weighing more than $150 \mathrm{~kg}$, and we are unable to draw any firm conclusions about dosing of LMW heparins for such patients. Consideration should be given to using peak anti-Xa levels to assess the degree of anticoagulation. Another alternative would be to use standard IV unfractionated heparin with monitoring of activated partial thromboplastin time for this patient group. On the basis of the limited data in the literature, some clinicians cap the dose at a body weight of $150 \mathrm{~kg}$ and check anti-Xa levels if therapy is planned for more than 3 days.

In conclusion, Canadian product monographs recommend that doses of LMW heparins be capped according to body weight, but the evidence supporting this practice is sparse and inconclusive. This dose-capping practice is inconsistent with LMW heparin management strategies used in other countries. Outcome data are conspicuously absent for obese patients with venous thromboembolism, and a large, prospective randomized study addressing this issue would be valuable. One advantage of the LMW heparins is consistent anticoagulation response with standardized weight-based regimens. Using a dose cap complicates therapy and has unclear effects on patient outcomes. Although only limited literature is available, most reports support dosing LMW heparins according to total body weight for patients weighing up to $150 \mathrm{~kg}$.

\section{References}

1. Büller HR, Agnelli G, Hull RD, Hyers TM, Prins MH, Rascob GE. Antithrombotic therapy for venous thromboembolic disease: the Seventh ACCP Conference on Antithrombotic and Thrombolytic Therapy. Chest 2004;126(3 Suppl):401S-428S.

2. Hirsh J, Raschke R. Heparin and low-molecular-weight heparin: the Seventh ACCP Conference on Antithrombotic and Thrombolytic Therapy. Chest 2004;126(3 Suppl):188S-203S.

3. Sanderink GJ, Le Liboux A, Jariwala N, Harding N, Ozoux ML, Shukla $\mathrm{U}$, et al. The pharmacokinetics and pharmacodynamics of enoxaparin in obese volunteers. Clin Pharmacol Ther 2002;72(3):308-318.

4. Fragmin [product monograph]. Kirkland (QC): Pfizer Canada; 2004.

5. Lovenox HP [product monograph]. In: Repchinsky C, editor. Compendium of Pharmaceuticals and Specialties. Ottawa (ON): Canadian Pharmacists Association; 2005.

6. Innohep [product monograph]. In: Repchinsky C, editor. Compendium of Pharmaceuticals and Specialties. Ottawa (ON): Canadian Pharmacists Association; 2005.

7. Fraxiparine ${ }^{\mathrm{TM}}$ Forte [product monograph]. In: Repchinsky C, editor. Compendium of Pharmaceuticals and Specialties. Ottawa (ON): Canadian Pharmacists Association; 2005. 
8. Cheer SM, Dunn CJ, Foster R. Tinzaparin sodium: a review of its pharmacology and clinical use in the prophylaxis and treatment of thromboembolic disease. Drugs 2004;64(13):1479-1502.

9. Canadian Community Health Survey: obesity among children and adults 2004. Ottawa (ON): Statistics Canada; 2005.

10. Gouin-Thibault I, Pautas E, Siguret V. Safety profile of different low-molecular weight heparins used at therapeutic dose. Drug Saf 2005;28(4):333-349.

11. Yee JYV, Duffull SB. The effect of body weight of dalteparin pharmacokinetics. A preliminary study. Eur J Clin Pharmacol 2000;56(4):293-297.

12. Bazinet A, Almanric K, Brunet C, Turcotte I, Martineau J, Caron S, et al. Dosage of enoxaparin among obese and renal impairment patients. Thromb Res 2005;116(1):41-50.

13. Hainer JW, Barrett JS, Assaid CA, Fossler MJ, Cox DS, Leathers T. Dosing in heavy-weight/obese patients with the LMWH, tinzaparin: a pharmacodynamic study. Thromb Haemost 2002;87(5):817-823.

14. Heizmann M, Baerlocher GM, Steinmann F, Horber FF, Wuillemin W. Anti-Xa activity in obese patients after double standard dose of nadroparin for prophylaxis. Thromb Res 2003;106(4-5):179-181.

15. Fragmin during Instability in Coronary Artery Disease (FRISC) study group. Low-molecular-weight heparin during instability in coronary artery disease. Lancet 1996;347(9001):561-568.

16. Spinler SA, Inverso SM, Cohen M, Goodman SG, Stringer KA, Antman EM; ESSENCE and TIMI 11B investigators. Safety and efficacy of unfractionated heparin versus enoxaparin in patients who are obese and patients with severe renal impairment: analysis from the ESSENCE and TIMI 11B studies. Am Heart J 2003;146(1):33-41.

17. Klein W, Buchwald A, Hillis SE, Monrad S, Sanz G, Turpie AG, et al. Comparison of low-molecular-weight heparin with unfractionated heparin acutely and with placebo for 6 weeks in the management of unstable coronary artery disease. Fragmin in unstable Coronary Artery Disease Study (FRIC). Circulation 1997;96(1):61-68. Erratum in: Circulation 1998;97(4):413.

18. Thrombolysis in Myocardial Infarction (TIMI) 11A Trial Investigators. Dose-ranging trial of enoxaparin for unstable angina: results of TIMI $11 \mathrm{~A}$. J Am Coll Cardiol 1997;29(7):1474-1482.

19. The FRAX.I.S. Study Group. Comparison of two treatment durations ( 6 days and 14 days) of a low molecular weight heparin with a 6-day treatment of unfractionated heparin in the initial management of unstable angina or non-Q wave myocardial infarction: FRAX.I.S. (FRAxiparine in Ischaemic Syndrome). Eur Heart J 1999;20(21):1553-1562.

20. Fifth Organization to Assess Strategies in Acute Ischemic Syndromes Investigators; Yusuf S, Mehta SR, Chrolavicius S, Afzal R, Poque J, Granger $\mathrm{CB}$, et al. Comparison of fondaparinux and enoxaparin in acute coronary syndromes. N Engl J Med 2006;354(14):1464-1476.

21. Antman EM, Morrow DA, McCabe CH, Murphy SA, Ruda M, Sadowski $Z$ et al; ExTRACT-TIMI 25 Investigators. Enoxaparin versus unfractionated heparin with fibrinolysis for ST-elevation myocardial infarction. N Engl J Med 2006;354(14):1477-1488.

22. Cohen M, Demers C, Gurfinkel EP, Turpie AG, Fromell GJ, Goodman S, et al.; Efficacy and Safety of Subcutaneous Enoxaparin in Non-Q-Wave Coronary Events Study Group. A comparison of low-molecular-weight heparin with unfractionated heparin for unstable coronary artery disease. N Engl J Med 1997;337(7):447-452.

23. Antman EM, McCabe CH, Gurfinkel EP, Turpie AG, Bernink PJ, Salein $\mathrm{D}$, et al. Enoxaparin prevents death and cardiac ischemic events in unstable angina/non-Q-wave myocardial infarction. Results of the Thrombolysis in Myocardial Infarction (TIMI) 11B trial. Circulation 1999;100(15):1593-1601.
24. Merli G, Spiro TE, Olsson CG, Abildgaard U, Davidson BL, Eldor A, et al.; Enoxaparin Clinical Trial Group. Subcutaneous enoxaparin once or twice daily compared with intravenous unfractionated heparin for treatment of venous thromboembolic disease. Ann Intern Med 2001;134(3):191-202.

25. Smith J, Canton EM. Weight-based administration of dalteparin in obese patients. Am J Health Syst Pharm 2003;60(7):683-687. Erratum in: Am J Health Syst Pharm 2003;60(13):1306.

26. Wilson SJ, Wilbur K, Burton E, Anderson DR. Effect of patient weight on the anticoagulant response to adjusted therapeutic dosage of lowmolecular-weight heparin for the treatment of venous thromboembolism. Haemostasis 2001;31(1):42-48.

27. Al-Yaseen E, Wells PS, Anderson J, Martin J, Kovacs MJ. The safety of dosing dalteparin based on actual body weight for the treatment of actue venous thromboembolism in obese patients. J Thromb Haemost 2005;3(1):100-102.

28. Barba R, Marco J, Martin-Alvarez H, Rondon P, Fernandez-Capitan C, Garcia-Bragado F, et al.; RIETE Investigators. The influence of extreme body weight on clinical outcome of patients with venous thromboembolism: findings from a prospective registry (RIETE). J Thromb Haemost 2005;3(5):856-862.

29. Charbonnier BA, Fiessinger JN, Banga JD, Wenzel E, d'Azemar P, Sagnard L; FRAXODI group. Comparison of a once daily with a twice daily subcutaneous low molecular weight heparin regimen in the treatment of deep vein thrombosis. Thromb Haemost 1998;79(5):897-901.

30. Rondina MT, Pendleton RC, Wheeler M, Rodgers GM. The treatment of venous thromboembolism in special populations. Thromb Res 2007; 119(4):391-402.

31. Duplaga BA, Rivers CW, Nutescu E. Dosing and monitoring of low-molecular-weight heparins in special populations. Pharmacotherapy 2001;21(2):218-234.

32. Hough LA, Kowalczyk A, LaMendola T, et al. Pharamcia Drug Inform Newsl 2001;5.

33. George-Phillips KL, Bungard TJ. Use of low-molecular-weight heparin to bridge therapy in obese patients and in patients with renal dysfunction. Pharmacotherapy 2006;26(10):1479-1490.

Peter Thomson, BSc(Pharm), PharmD, is with the Department of Pharmaceutical Services, Health Sciences Centre, Winnipeg, Manitoba.

Cynthia Brocklebank, BScPharm, PharmD, is with the Pharmacy Department, Peter Lougheed Centre, Calgary, Alberta.

William Semchuk, BSP, MSc, PharmD, is with the Department of Pharmacy Practice, Regina Qu'Appelle Health Region, Regina, Saskatchewan.

Address correspondence to:

Peter Thomson

Department of Pharmaceutical Services

Health Sciences Centre

820 Sherbrook Street

Winnipeg MB R3A 1 R9

e-mail: pthomson@hsc.mb.ca 